\title{
The Impact of Movies on Tourism among Egyptian Youth
}

\author{
Dina Farouk Abou Zeid \\ Professor at Mass Communication Department, \\ Faculty of Arts, Ain Shams University and Dean of Media Sciences Faculty \\ IAEMS (International Academy For Engineering and Media Science), \\ Egypt.
}

DOI: https://doi.org/10.36941/mjss-2021-0047

\section{Abstract}

The research study aims to examine the impact of movies on tourism among Egyptian youth by studying the different genres of movies and the different types and forms of tourism besides applying infotainment to discover the elements of information and entertainment in movies which encourage the youth to travel. A survey is conducted of a disproportionate stratified sample of 500 Egyptian university students divided equally between private and public universities and between males and females who have passion for traveling, travel at least once a year and are members of travel Facebook groups. The results show that Egyptian and non-Egyptian movies encourage Egyptian university students to travel abroad. The most popular types of movie-induced tourism among the youth are traveling to destinations portrayed in movies, organized tour of portrayed locations, tour of studio sets and movie-themed park. The findings indicate that movie- induced tourism is affected by movies' infotainment.

Keywords: movie-induced tourism, media tourism, culture tourism, movies tourism, infotainment, Egyptian youth

\section{Introduction}

Cinema is very popular among Egyptians especially young generations who are being exposed in these last years to movies from different countries through internet and satellite television channels (Farouk, Abou Zeid, 2019). Nowadays, the youth watch Turkish, Indian, Spanish, Japanese and North Korean movies which were not available for them in the past. However, American movies are still the most dominant foreign movies in movie theaters and public terrestrial television channels in Egypt. And, young Egyptians are still big fans of Hollywood cinema (Armbrust, 2004). Also, the youth watch Egyptian movies which are called Near East Hollywood due to their success in the Arab world (Shafik, 1998). These Egyptian and non-Egyptian movies can play various roles including movie-induced tourism which refers to the role of cinema in motivating people to travel to destinations portrayed in movies.

Movie-induced tourism is an example of culture tourism which refers to the motivation of visiting a country after the popularity of its culture (Kim \& Reijnders, 2017). Many research studies indicate that destinations portrayed in movies witnessed an increase in the number of tourists for example in U.S.A, U.K, Australia, Italy and New Zealand. This is due to movies which play a role in creating the tourist gaze, a term used to refer to the formation and construction of destinations and 
landscapes' meanings through signs, discourses, knowledge and experiences (Huang, 2013). Armchair tourists who travel to destinations through watching movies without physically visiting the destinations can become movies' tourists when they take the decisions to travel to movies' locations. Different genres of movies can encourage different types of movie-induced tourism and not only travel or road movies which are not well-known genres in Egypt.

Furthermore, Infotainment is a new term used to explain how media can mix between information and entertainment establishing new genres and formats especially on television (Chepornyuk, 2018). There is a lack of studies about infotainment in media. Most of the studies available focus on political information on television. So, there is a need to apply and examine infotainment on different types and kinds of media and on different types and kinds of information.

Movies in general and movies about travel in particular are examples of infotainment because they are not only a source of entertainment, but also a source of information about many domains including tourism. Movies' infotainment is influencing movie-induced tourism because movies contain information about tourism presented through entertainment elements which encourage audiences to travel making movies a source of infotainment. However, there is a lack of studies about the relation between movies and tourism from the perspectives and approaches of infotainment.

Therefore, there is a need to study movie-induced tourism among Egyptian youth by applying infotainment approach. This research study aims to conduct a survey of 500 Egyptian university students to examine the following: the impact of movies on the types and forms of tourism, the impact of the genres of movies on tourism, the popular types of movie-induced tourism and the impact of movies' infotainment on movie-induced tourism.

\section{Literature Review}

\subsection{The Relation between Movies and Tourism}

\subsubsection{Armchair Tourism}

Armchair tourism refers to travelling through books, television, photos, movies, internet, new media and digital media without physically visiting any destinations (Jorgensen, 2014) and without travel's expenses (Landry, 2006). The armchair tourists escape from reality and imagine living in different environments (Maziersk \& Walton, 2006). Also, they are informed about various locations while being entertained (Damkjoer \& Waade, 2014). Technologies such as ${ }_{3} \mathrm{D}$ and virtual stimulated worlds have developed the experiences of armchair travelers (Baxter, 2011). Armchair tourism can lead to tourism in real locations (Hallett \& Kaplan-Weinger, 2010). And, when this role is played by movies, it is called movie tourism, film tourism, cinematic tourism, film-induced tourism, movie-induced tourism, teletourism or media tourism (Karpovich, 2010).

\subsubsection{Movie-Induced Tourism}

Movie-induced tourism is one of the terms used to refer to the increase of tourism in countries and locations which are portrayed in movies such as Wallace Monument after the release of the movie "Braveheart", Fort Hayes after "Dances with Wolves", National Parks in Sydney after "Mission Impossible 2", Thailand after "The Beach" and different UK sites after "Harry Potter" (Juskelyte, 2016). There are two main categories of movie-induced tourism which are on-location and off-location. Onlocation includes tourism in the actual and natural destinations of movies such as landscapes, streets, buildings, historical sites, sets left by producers and tours of movies' locations. However, off-location refers to built and artificial places such as movies' studios' tours and theme parks (Roesch, 2009). Also, film festivals and movies' premieres encourage tourism and are considered examples of movieinduced tourism (Beeton, 2016).

Movies provide information about destinations. These information can create a first image 
about a place or can change its initial image to form a new one. The positive image leads to a desire to travel. Then, the person takes a decision to visit the movies' destinations (Hahm, Upchurch, \& Wang, 2008).

Some Scholars have explained movie-induced tourism through push and pull theory by applying pull factors on movies' presentation of attractions such as sea, sun, sand and culture besides applying push factors on tourists' psychological and physiological motivations such as escape from frustrating settings and conditions (Riley \& Van Doren, 1992).

There are three types of movies' tourists which are serendipitous, general and specific. The serendipitous tourists are in a movie destination by chance and are motivated by novelty and social interaction. However, general tourists are not attracted to a movie destination, but are motivated by nostalgia, education and novelty. On the other hand, specific tourists are looking for destinations portrayed in movies and are motivated by nostalgia, romance, fantasy, self-identity, pilgrimage and self-actualization (Gjorievski \& Melles Trpkova, 2012).

Virtual reality technologies persuade people to visit touristic destinations and to change previous attitudes toward locations especially when the users experience a high degree of spatial presence in stimulated environments (Tussyadiah, Wang, \& Jia, 2017).

Movies' production in specific locations not only increase tourism, but also create business and employment opportunities besides the development of these areas (Ward \& O' Regan, 2009). So, countries and destinations marketing organizations attract movies' production companies to film in specific locations through facilities and services including funds, logistics, labor and accommodation (Niziol, 2009).

Movie-induced tourism follows different phases which include introduction of the destinations, increase of tourists' number, stagnation and decline of tourism. But, the challenges of the decrease of movies' impact on tourism could be solved by repeating releasing the movies on television, DVD and different platforms which can attract new generations who did not witness the first release of the movies in movie theaters (Tomala \& Faber, 2011).

Cinema can have a negative impact on tourism. For example, if movies negatively portray a destination, they will discourage tourists to visit it (Zignale, 2011). Moreover, movies can manipulate the culture, authenticity and identity of a country when locations are presented through unreal, fantasy and invented stories besides virtual and digitized images. Therefore, tourists can be attracted to the locations that are staged in movies more than real and natural sites (Tzanelli, 2007).

There are few studies about movie-induced tourism and most of them have western perspectives (Beeton, 2006) and are applied on movies in general, however, there are movies' genres that are specialized in travel such as travelogues and road movies.

\subsubsection{Travelogue and Road Movies}

Travelogue movies are non-fiction movies about travel (Peterson, 2013) which mainly aim to represent countries, cultures and destinations. They are types of documentary and ethnographic movies that inform, educate and entertain audiences (Ruoff, 2006). However, a road movie is a genre in which the main characters go on a trip by cars, trucks or motorcycles. The main theme of these movies is the journey which is used to discuss freedom, social issues, masculinity, escape from daily life (Cohan \& Hark, 2002), mobility, self-criticism and self-discovery (Lie, 2017). This genre is concerned with social and cultural criticism which is based on the conflict between stability and rebellion (Holohan, 2011). Also, the movies associate road trips with hope, adventure, excitement, risk, danger, new beginnings and changing life (Eyerman \& Lofgren, 1995). Some of the road movies portray the differences between urban and rural areas 'culture and traditions in postmodernity (Nestingen, 2005).

Travel, movement and speed have been found in movies before road movies' genre (Everett, 2009). For example, Hollywood movies have been presenting roads and pathways in Western movies. But, road movies have appeared as a new genre to show modernity and technological advances which 
are portrayed through motorized vehicles. This genre can be categorized into three types which are the outlaw/domestic drama, quest and existential movies. In the outlaw/domestic drama movies, the characters escape from a situation such as tragedy, crime or disaster. On the other hand, in the quest movies, characters look for something for example freedom, survival or self-transformation. However, in the existential movies, the characters do not have specific goals for the trips, but live a process of self-transformation (Alford, 2018).

Many European road movies focus on discussing nationalism and citizenship especially among different generations of immigrants. These movies are presenting foot or public transit's trips, however, American road movies are showing car or motorbikes' trips (Gott, 2013). Latin American road movies are influenced by fiction, neorealist and documentary movies' features. The movies are characterized by long takes, panoramic shots, natural lighting and shooting on location. Also, they are different from Hollywood road movies in portraying the protagonists from different social classes, races and gender which are usually underrepresented in cinema (Garibotto \& Perez, 2016).

Audiences are not only entertained, but also informed about tourism and travel while watching movies in general and movies about travel in particular. So, cinema is considered a source of infotainment which can be applied on the relation between movies and tourism. Also, information about destinations is one of the first steps in movie-induced tourism.

\subsubsection{Infotainment}

The term infotainment has emerged in the eighties to refer to a new genre of media content which combines information and entertainment elements. Although this global phenomenon is usually used to refer to television (Otto, Glogger, \& Boukes, 2017), it can be found in other types and kinds of media such as print, radio and internet (Surette, 2015). Also, infotainment is usually applied on political communication and news (Brants, 1998). However, it can be found in different content such as docudramas, talk-shows and reality television (Thussu, 2011).

Infotainment is characterized by presenting informative content through entertainment elements (Brants \& Neijens, 1998) including sensational stories, emotional events (Buckingham, 2004), lots of music and graphics and pretty anchors (Schultz, 2012). Also, the audiences' responses are emotional rather than rational (Carter \& Allan, 2013). Infotainment makes the differences between news and entertainment disappear (Hasan, 2008). And, soft news is considered an example of infotainment (Nguyen, 2012). Furthermore, information technology, multimedia and new media create an infotainment society (Kellner, 2003). Rich media enhance infotainment through live streaming, interactivity and online video (Lea-Greenwood, 2013).

Infotainment can narrow knowledge gap by attracting audiences who are not interested in information (Lee, 2002). For example, it attracts young viewers to news and public affairs' shows (Thussu, 2003). And, late-night comedy and daytime talk shows which are considered examples of infotainment increase political engagement and participation during presidential elections (Moy, Xenos, \& Hess, 2005). On the other hand, infotainment is criticized because it focuses on scandals and politicians' private lives besides providing less information and more entertainment (Jebril, Albaek, \& Devreese, 2013). It is influenced by media commercialization, privatization, competition and marketing which make media seek audiences and advertising by adopting entertainment formats (Thussu, 2008).

Research studies have been conducted about infotainment since 1980, but the term still needs a clear definition and more studies to determine its common properties (Marinov, 2020) and to be applied on different kinds of media.

\section{Comments about Literature Review}

Reviewing the literature shows that there are rare studies about the relation between movies and tourism and most of the studies conducted are from marketing and advertising perspectives to 
examine the increase number of tourists in destinations. Also, there is a lack of studies conducted from the point of views of the audiences. Movie- induced tourism has been studied through different genres of movies without focusing on travelogues and road movies. The literature review shows that infotainment is rarely applied on media and cinema research studies in general and on movieinduced tourism in particular. Moreover, Arab and Egyptian researchers are not interested in studying movies' tourism and infotainment. Therefore, this research study is important and needs to be conducted.

\section{The Objectives of the Study}

The study aims to examine the following:

The impact of movies on tourism among Egyptian youth

The types of movie-induced tourism among Egyptian youth

The impact of movies' infotainment on movie-induced tourism among Egyptian youth

\section{Methodology}

A survey of 500 Egyptian university students was conducted through electronic self-administered questionnaires sent and received via emails and Facebook messenger. The research study used disproportionate stratified sample by selecting equal numbers of students from public and private universities in Egypt who are members in travelers' Facebook groups, have passion to travel in Egypt and abroad, travel abroad at least once a year and are considered specific movies' tourists because they travel to destinations portrayed in movies. Also, the sample was divided equally between females and males. The disproportionate stratified sample is used when every stratum does not have the same sampling fraction and is not proportional to the size of the stratum. It belongs to probability sample which gives the chance to all the population to be selected (Singh, 2007).

The questionnaires were in Arabic language which is the mother tongue of the students and contained closed- ended questions about the five research questions of the study besides open-ended questions mainly to let the youth give examples of the movies that apply to their answer choices. The questionnaires design was composed of three main parts including questions about tourism, movies and infotainment. They were used to collect quantitative data and present descriptive statistics of the frequencies and percentages.

The students were selected from travelers' Facebook groups whether public or closed groups. The researcher sent private messages to members of the groups asking them to participate in the survey if they are university students, have passion for traveling and travel abroad at least once a year. The sample included the first 125 females from public universities, 125 females from private universities, 125 males from public universities and 125 males from private universities who sent a message to confirm their participation and their demographic characteristics that fit the criteria of the research. The questionnaires were sent through emails or Facebook messages according to what was convenient for the respondents, but most of the students preferred Facebook messages. Also, many students were very excited about the survey because they liked to talk about their travel experiences which was one of their reasons of joining and participating in travelers' Facebook groups.

The validity was tested by 10 Egyptian mass media professors who reviewed the questionnaire which was modified according to their comments and views.

This methodology was different from previous researches because it gathered views and attitudes of the tourists, however, previous researches focused on content analysis of movies or on the number of tourists in destinations portrayed in movies. This study and its methodology introduced movie-induced tourism from different approaches and perspectives related to media instead of tourism and marketing.

Based on the theoretical background and literature review, the research study seeks to answer the following questions: 
RQ1: What is the impact of movies on the types of tourism among Egyptian youth?

RQ2: What is the impact of movies on the forms of tourism among Egyptian youth?

RQ3: What is the impact of the genres of movies on tourism among Egyptian youth?

RQ4: What are the types of movie-induced tourism among Egyptian youth? youth?

RQ5: What is the impact of movies' infotainment on movie-induced tourism among Egyptian

\subsection{Results/Findings}

Figure 1 below shows that international tourism was influenced by movies more than domestic tourism among Egyptian youth. All university students in the sample $(\mathrm{N}=500)$ mentioned that nonEgyptian and Egyptian movies encouraged them to travel abroad whether the movies were available on movie theaters, television or internet. The result agreed with other studies indicating that young people were more influenced by movies' tourism than other generations (Oviedo-Garcaa, Castellanos-Verdugo, Trujillo-Garcia, \& Mallya, 2016). The youth were attracted to travel to the countries which they watch their productions such as U.S.A, India, Turkey, Spain, Japan and South Korea. Also, university students were interested in visiting countries which they did not watch their productions such as Italy, France, Greece and U.K, but these countries were portrayed in American, Indian and Egyptian movies which the youth liked to watch. These results showed that globalization played a role in the popularity of movies from different countries leading to the popularity of these countries' culture and tourism. However, few students $(\mathrm{N}=105)$ said that movies particularly Egyptian movies encouraged them to travel to destinations in Egypt.

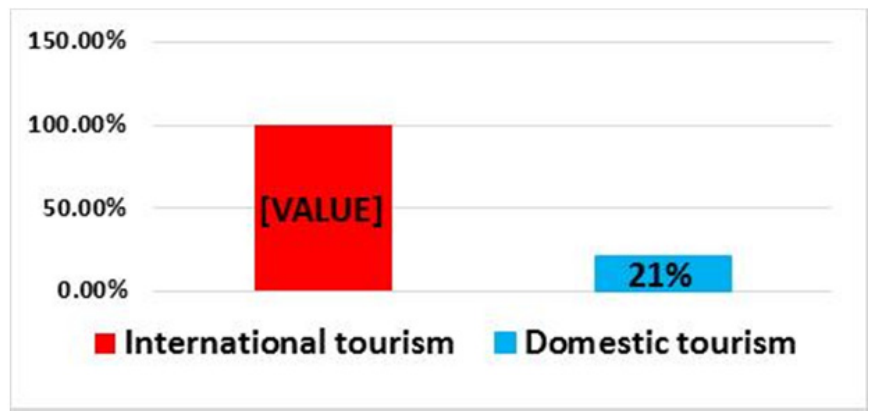

Figure 1: The impact of movies on the types of tourism among Egyptian youth $(\mathrm{N}=500)$ Source: The researcher

As seen in table 1, most of Egyptian university students mentioned five forms of tourism which were influenced by movies. These forms included cultural tourism (99.6\%) in France and Italy, beach tourism (99\%) in Spain, Greece and Egypt, leisure tourism (83.2\%) in U.S.A, wildlife tourism (6o\%) in African countries and finally adventure tourism (41.4\%) in Asian countries.

Table 1: The impact of movies on the forms of tourism among Egyptian youth $(\mathrm{N}=500)$

\begin{tabular}{lcc}
\hline The impact of movies on the forms of tourism among Egyptian youth & Frequencies & Percent \\
\hline Cultural tourism & 498 & 99.6 \\
\hline Beach tourism & 495 & 99 \\
\hline Leisure tourism & 416 & 83.2 \\
\hline Wildlife tourism & 300 & 60 \\
\hline Adventure tourism & 207 & 41.4 \\
\hline
\end{tabular}


Source: The researcher

As shown in table 2, the majority of Egyptian youth in the sample indicated seven genres of movies that encouraged them to travel. These genre were romance movies $(98.2 \%)$, comedy movies $(85 \%)$, adventure movies (75.4\%), road movies (62.6\%), action movies (52\%), musical movies (20\%) and finally animation movies (16.6\%). It was noticed that Egyptian university students were not aware of travel movies as a genre.

Table 2: The impact of the genres of movies on tourism among Egyptian youth $(\mathrm{N}=500)$

\begin{tabular}{lcc}
\hline The impact of the genres of movies on tourism among Egyptian youth & Frequencies & Percent \\
\hline Romance movies & 491 & 98.2 \\
\hline Comedy movies & 425 & 85 \\
\hline Adventure movies & 377 & 75.4 \\
\hline Road movies & 313 & 62.6 \\
\hline Action movies & 260 & 52 \\
\hline Musical movies & 100 & 20 \\
\hline Animation movies & 83 & 16.6 \\
\hline
\end{tabular}

Source: The researcher

Table 3 reveals that various types of movie-induced tourism were popular among Egyptian youth including visiting real destinations portrayed in movies (100\%), organized tour of portrayed location $(98.8 \%)$, tours of studio sets $(90.2 \%)$ and movie-themed parks $(84.8 \%)$. On the other hand, it was found that movies festivals (20.2\%) and movies' premieres $(5.4 \%)$ had few percentages showing that they were not popular types of movie-induced tourism among the youth.

Table 3: The types of movie-induced tourism among Egyptian youth $(\mathrm{N}=500)$

\begin{tabular}{lrr}
\hline $\begin{array}{l}\text { The impact of movies' entertainment on movie-induced tourism among } \\
\text { Egyptian youth }\end{array}$ & Frequencies & Percent \\
\hline Shooting location & 500 & 100 \\
\hline Plot & 495 & 99 \\
\hline Famous stars & 494 & 98.8 \\
\hline Production and directing & 193 & 38.6 \\
\hline Music and songs & 100 & 20 \\
\hline Costume design, makeup and hairstyling & 94 & 18.8 \\
\hline Editing and visual effects & 81 & 16.2 \\
\hline
\end{tabular}

Source: The researcher

As indicated in table 4, movie-induced tourism among Egyptian youth was influenced by destinations' information included in the movies especially about touristic sites (99.2\%), culture and traditions $(84.4 \%)$, safety $(80.8 \%)$ and weather $(79.8 \%)$. These information could be found through the plots even if the movies were not focusing on travel. However, transportation (41.4\%), history (37.4\%), food (31\%), expenses (20.6\%), accommodation (18.4\%), language (18.2\%), currency (17.6\%) and laws $(9 \%)$ were not important factors in encouraging the youth to travel because movies did not provide these information about destinations. 
Table 4: The impact of movies' information on movie-induced tourism among Egyptian youth $(\mathrm{N}=500)$

\begin{tabular}{lcc}
\hline $\begin{array}{l}\text { The impact of movies' information on movie-induced tourism among } \\
\text { Egyptian youth }\end{array}$ & Frequencies & Percent \\
\hline Information about touristic sites & 496 & 99.2 \\
\hline Information about culture and traditions & 422 & 84.4 \\
\hline Information about safety & 404 & 80.8 \\
\hline Information about the weather & 399 & 79.8 \\
\hline Information about transportation & 207 & 41.4 \\
\hline Information about history & 187 & 37.4 \\
\hline Information about food & 155 & 31 \\
\hline Information about the expenses & 103 & 20.6 \\
\hline Information about accommodation & 92 & 18.4 \\
\hline Information about the language & 91 & 18.2 \\
\hline Information about currency & 88 & 17.6 \\
\hline Information about laws & 45 & 9 \\
\hline
\end{tabular}

Source: The researcher

Table 5 below shows that movie-induced tourism among Egyptian youth was influenced by entertainment factors in movies particularly shooting locations (100\%), plot (99\%) and famous actors (98.8\%). On the other hand, production and directing (38.6\%), music and songs (20\%), costume design, makeup and hairstyling (18.8\%) and finally editing and visual effects (16.2\%) were not important factors in encouraging the youth to travel.

Table 5: The impact of movies' entertainment on movie-induced tourism among Egyptian youth $(\mathrm{N}=500)$

\begin{tabular}{lcc}
\hline $\begin{array}{l}\text { The impact of movies' entertainment on movie-induced tourism among } \\
\text { Egyptian youth }\end{array}$ & Frequencies & Percent \\
\hline Shooting location & 500 & 100 \\
\hline Plot & 495 & 99 \\
\hline Famous stars & 494 & 98.8 \\
\hline Production and directing & 193 & 38.6 \\
\hline Music and songs & 100 & 20 \\
\hline Costume design, makeup and hairstyling & 94 & 18.8 \\
\hline Editing and visual effects & 81 & 16.2 \\
\hline
\end{tabular}

Source: The researcher

\section{Discussion}

All university students in the sample are influenced by old and new non-Egyptian and Egyptian movies which encourage them to travel abroad. Concerning American movies, they have been the most popular and widespread in Egypt and young generations have been used to be exposed to Hollywood cinema and American media since their childhood. So, most of the sample are motivated to travel to U.S.A even if the movies are not about travel, but portray American atmosphere and lifestyles such as the movie "You've Got Mail". Also, movie-induced tourism is found in countries portrayed in American movies such as Italy featured in the movie "The Talented Mr. Ripley", Spain in "Vicky Cristina Barcelona" and Greece in "Zorba the Greek".

Regarding Bollywood movies, they are very popular in Egypt especially through private satellite 
channels available on the Egyptian Satellite Nilesat. They motivate the audiences not only to travel to India, but also to various countries especially in Europe for instance the movie "Jab Harry Met Sejal" which features many cities in Europe including Prague, Amsterdam, Vienna, Lisbon and Budapest. Not few students in the sample watch new Indian movies because they are filmed in different countries and cities in Europe which satisfy their passion of travel.

Also, Spanish movies have been popular among Egyptian youth after the success of the Spanish TV series "La Casa De Papel" on Netflix. So, they have started to look for Spanish movies on the internet which motivate them to travel there such as the movie "Ibiza" and "Y Tu Mama Tambien".

Moreover, Turkish TV series are very successful among Egyptians especially women and the youth after being shown on Arab satellite channels for the first time in 2007. So, university students are looking for Turkish movies to watch their favorite Turkish actors and actresses for instance the movie "Kardesim Benim". In these last years, shooting locations in Turkey are becoming popular attractions among Egyptians and Arabs.

Concerning Japan, Egyptian youth have been used to watch anime in their childhood on private satellite channels which has made them attracted to Japanese movies, media and culture which motivate them to travel to Japan for example the anime movie "Kimi No Na Wa".

Regarding South Korea, university students like k-pop and Korean TV series shown on private satellite channels which make them searching for North Korean movies on the internet trying to discover the country and its culture for example the movie "Psychokinesis". These media including movies encourage tourism in the country.

On the other hand, tourism in Egypt is rarely influenced by movies because its touristic attractions and destinations are rarely portrayed in Egyptian and non-Egyptian movies. The few nonEgyptian movies that promote for tourism are about historical events for example the American movie of 1963 "Cleopatra". And, although Egyptian movies attract Arabs to visit Egypt especially Cairo, they are not promoting for tourism among Egyptian youth. Most of Egyptian movies do not show the beaches, deserts, ancient Egyptian monuments, museums and parks. Few movies play this role for example Egyptian movie of 1967 "Love in Karnak" which portrays Luxor, a city in Upper Egypt and its ancient Egyptian monuments such as Karnak Temple and Egyptian movie of 2007 "Naama Bay" which features Sharm El-Sheikh, a city in South Sinai Governorate.

The research study finds that movies influence different forms of tourism among Egyptian youth such as cultural tourism, beach tourism, leisure tourism, wildlife tourism and adventure tourism. Concerning culture tourism, it is found in movies featuring museums, historical sites and monuments for example the movie "The Da Vinci Code" showing the Louvre museum in Paris and "Night at the museum" portraying The American Museum of National History in New York City. Beach tourism is motivated by movies featuring oceans, seas and beaches even if the plots are not about beach vacations for instance "Before Midnight" in Greece. Leisure tourism is induced by movies presenting entertainment and fun such as the movie "Indecent Proposal", "Casino" and "The Hangover" showing the atmosphere of Las Vegas. Wildlife tourism is encouraged through movies involving wild animals and naturals plants for example the movie "Out of Africa" and "Tarazan". Finally, adventure tourism is promoted by movies presenting adventure, danger, risks and physical activities for instance the movie "Seven Years in Tibet" and "Everest". The students believe that many movies can encourage more than one form of tourism so it is hard to categorize them.

The findings show that Egyptian university students are not aware of the genre of travel movies. So, they do not refer to this genre while mentioning the movies' genres motivating tourism. According to many research studies, movies' genres influence movie-induced tourism (Abd Rahman, Dawam, \& Chan, 2019) and this result agrees with Egyptian youth who are influenced by romance movies for example the Turkish movie "Ask Sana Benzer", comedy movies for instance the Egyptian movie "Hamam in Amsterdam", adventure movies such as "Life of Pi", road movies for example the Indian movie "Zindagi Na Milegi Dobara", action movies for instance "Mission: Impossible- Fallout", musical movies such as "Mamma Mia!" and finally animation movies for example "Penguins of Madagascar". University students in the sample believe that all the genres of movies encourage them 
to travel even if travel is not in the plot because these movies show new destinations and locations. And, movie- induced tourism among Egyptian youth is not only influenced by new movies, but also by old movies such as "Casablanca", "Roman Holiday", "An American in Paris" and "Fanny". The students believe that all movies' genres can motivate tourism if they portray unknown destinations or if they contain travel's procedures and experiences. Moreover, it is noticed that categorizing movies is hard for youth because they consider many movies belong to more than one genre.

The types of movie-induced tourism among Egyptian youth include visiting real destinations portrayed in movies for example travelling to Italy, India and Indonesia which are portrayed in the movie "Eat Pray Love", Italy in "The Tourist", Japan in "Lost in Translation" and Thailand in "The Beach". Furthermore, the youth visit specific destinations in countries which are featured in movies such as cities for example Venice in the movie "The Tourist", fountains for instance Trevi Fountain in "La Dolce Vita", parks such as Central Park in New York City in "Friends with Benefits", waterfalls for example Niagara Falls in "Niagara”, lakes for instance Lake Como in "Ocean's Twelve" and buildings such as the Empire State Building in "Sleepless in Seattle". Another popular type of movie-induced tourism among Egyptian youth is organized tours of portrayed locations (98.8\%) for example the tour of the movie "The Third Man" in Vienna, the tour of "Sound of Music" in Salzburg and the tour of New York City movies. Moreover, many university students are interested in the tours of a studio set and movie-themed parks for instance Universal Studios Hollywood. Few Egyptian students in the sample refer to two types of movie-induced tourism which are movies festivals such as Cannes Film Festival and movies' premieres for example Egyptian movies' premieres in Cairo movie theaters.

The results show that infotainment is an approach that can be used while studying movies in general and movie-induced tourism in particular because studies prove that movies are sources of both information and entertainment (Spears, Josiam, Kinley, \& and Pookulangara, 2013). Therefore, movies provide information about touristic sites, culture and traditions, safety and the weather. For example, the Egyptian movie of 1963 "The Naked Truth" features Abu Simbel temples in Aswan Governorate in Egypt. The movie "My Big Fat Greek Wedding" presents Greek culture, traditions and customs especially during weddings. The Egyptian movie of 1984 "Went Out and Never Came" shows safety, security, peace and relaxation of the life in the villages in Egypt. The Egyptian movie of 2000 "Shorts, Shirt and Cap" portrays the unique weather of Sharm El-Sheikh, city in South Sinai. This is considered one of the first step of movie-induced tourism which includes getting information about a destination to create an image about it. If the image is positive, it encourages the audiences to travel.

Moreover, there are elements of entertainment in movies which encourage Egyptian youth to travel including shooting locations, plot and famous stars which agree with other studies conducted on different audiences (Ismail, Sumarjan, Khan, \& Hanafiah, 2017). The shooting location is an important factor attracting the audiences who have passion for traveling. Also, famous stars attract their fans to live the movies' experiences in real locations and many studies prove the influential role of actors and actresses on movie-induced tourism (Hudson \& Ritchie, 2006). Concerning the plot, when audiences enjoy the plot of a movie, they want to live it in real locations to feel the same emotions of joy and entertainment which they feel while watching the movies. The above results show that armchair tourism leads to movie-induced tourism.

Also, the findings indicate that gender is not affecting the impact of movie-induced tourism among Egyptian youth. There are not any differences between the respondents according to their gender. Females and males are being influenced by the movies which encourage them to travel abroad.

\section{Conclusion}

It can be concluded that movies play an important role in encouraging tourism among Egyptian youth. But, international tourism is being influenced more than domestic tourism. Therefore, Egypt needs to be more portrayed in Egyptian and non-Egyptian movies. Moreover, the results indicate that old or new movies from various genres promote for the different types and forms of tourism. Young 
Egyptians believe that all movies can play this role even if the movies are not about travel, but feature new destinations. Furthermore, many types of movie-induced tourism are popular among the youth such as visiting real destinations portrayed in movies, organized tours of portrayed locations and tours of studio sets. However, movies' festivals and movies' premieres are less popular among university students in the sample.

The findings reveal that infotainment can be applied on movies and tourism because cinema can inform the audiences about tourism while entertaining them. For example, movies contain information about destinations that encourage tourism including information about touristic sites, culture and traditions, safety and weather. Also, there are elements of entertainment in the movies that induce tourism for instance shooting locations, plot and famous stars. Therefore, movies have elements of information and entertainment which are associated with tourism and travel.

Egyptian producers should promote for tourism in their movies. And, ministry of tourism should implement movie-induced tourism. Also, ministry of culture should offer more facilities to Egyptian and non-Egyptian movies to film in touristic sites. Many scholars suggest that countries should give advantages to production companies to attract them to film in their sites (Dimoudis, 2018).

In conclusion, it is found that movie-induced tourism is an important phenomenon that Egypt should use to promote for its tourism through Egyptian and non-Egyptian movies.

\section{Limitation and Future Research Directions}

This research study focuses on movie-induced tourism among Egyptian university students in public and private universities who have passion for traveling. And, they travel at least once a year and are considered specific movies' tourists who travel to destinations portrayed in movies. Therefore, there is a need to understand the phenomenon on other ages and generations and on other types of movies' tourists in Egypt and other developed and developing countries.

Moreover, this study tries to examine movies' tourism from media approaches and perspectives because most of the literature review available are from tourism field. But, the phenomenon still needs to be more analyzed from different media theories and approaches besides movies' aesthetics.

Infotainment is rarely used in studying different types and kinds of mass media and mass communication issues. It is usually used to study news and politics. Therefore, this research shows that infotainment can be applied on different media such as movies and on different fields such as tourism. However, researchers should discover the other domains and issues that can be a source of infotainment among audiences.

\section{References}

Abd Rahman, N., Dawam, Z.A., \& Chan, J.K. (2019). The characteristics of film products to induce tourism. Journal of Tourism, Hospitality and Environment Management, 4(16), 84-99. https://doi.org.10.35631/JTHEM.416007

Alford, S. E. (2018). Easy riders lost in America: Marx, mobility and the Hollywood road movie. Class, Race and Corporate Power, 6(2). https://doi.org.10.25148/crcp.6.2.008308

Armbrust, W. (2004). Egyptian cinema on stage and off. In Andrew Shryock (Eds.), Off stage/on display: Intimacy and ethnography in the age of public culture (pp. 69-10o). CA: Stanford University Press.

Baxter, A., \& Pieszek, L. (2011). Armchair tourism. In Alexis Papathanassis (Eds.). The long tail of tourism (pp. 171183). Wiesbaden: Gabler.

Beeton, S. (2006). Understanding film-induced tourism. Tourism Analysis, 11(3), 181-188. https://doi.org/10.3727 /108354206778689808

Beeton, Sue (2016). Film-induced tourism (2nd ed.). Bristol: Channel View Publications.

Brants, K. (1998). Who's afraid of infotainment?. European Journal of Communication, 13(3), 315-335.

Brants, K., \& Neijens, P. (1998). The infotainment of politics. Political Communication, 15(2), 149-164.

Buckingham, J. I. (2004). "Newsmaking" criminology or "infotainment" 1 criminology?. Australian \& New Zealand Journal of Criminology, 37(2), 253-275. https://doi.org/10.1375/acri.37.2.253 
Carter, C., \& Allan, S. (2013). 'If it bleeds, it leads': Ethical questions about popular journalism. In David Berry (Eds.), Ethics and media culture: Practices and representations (pp. 132-153). MA: Focal Press.

Chepornyuk, Anastasiya (2018). Infotainment as media communication neo-genre: Functional and stylistic analysis. Actual Issues of Ukrainian Linguistics: Theory and Practice, 37, 124-140. https://apultp.knu.ua/index.php/APULTP/article/view/9

Cohan, Steven, \& Hark, Ina Rae (2002). Introduction. In Steven Cohan, \& Ina Rae Hark (Eds.), The Road Movie Book (pp. 1-14). NY: Routledge.

Damkjoer, Maja Sonne, \& Waade, Anne Marit (2014). Armchair tourism: The travel series as a hybrid genre. In Folker Hanusch, \& Elfriede Fursich (Eds.), Travel journalism: Exploring production, impact and culture (pp. 39-59). London: Palgrave Macmillan.

Dimoudis, Nikolaos (2018). Film-induced tourism, the case study of 'Game of Thrones' TV series (Unpublished master's thesis). International Hellenic University, Thessaloniki, Greece.

Everett, W. (2009). Lost in Transition? The European road movie, or a genre "adrift in the cosmos". Literature/Film Quarterly, 37(3), 165-175.

Eyerman, R., \& Lofgren, O. (1995). Romancing the road: Road movies and images of mobility. Theory, Culture \& Society, 12(1), 53-79.

Farouk Abou Zeid, Dina (2019). Happy media among Egyptian high school girls. Global Media Journal Turkish Edition, 10(19), 332-355.

Garibotto, Veronica, \& Perez, Jorge (2016). Introduction: Reconfiguring precarious landscapes: The road movie in Latin America. In Veronica Garibotto, \& Jorge Perez (Eds.), The Latin American road movie (pp. 1-28). NY: Palgrave Macmillan.

Gjorgievski, Mijalce, \& Melles Trpkova, Sinolicka (2012). Movie induced tourism: A new tourism phenomenon. UTMS Journal of Economics, 3(1), 97-104.

Gott, M. (2013). Traveling beyond the national: Mobile citizenship, flexible identities, and layered republicanism in the French return road movie. Contemporary French Civilization, 38(1), 73-95.

Hahm, J., Upchurch, R., \& Wang, Y. (2008). Millennial students, movies, and tourism. Tourism Analysis, 13(2), 189204.

Hallett, R. W., \& Kaplan-Weinger, J. (2010). Official tourism websites: A discourse analysi perspective tourism and cultural change (Vol. 23). Bristol: Channel View Publications.

Hasan, Daisy (2008). Neil Postman and the rise of infotainment in India. In Philip Bounds, \& Mala Jagmohan (Eds.) Recharting media studies: Essays on neglected media critics (pp. 227-248). Bern: Peter Lang.

Holohan, Conn (2011). Wrong turns: Radical spaces in the road movies of Tony Gatlif. Transnational Cinemas, 2(1), 21-35.

Huang, Guanxiong (2013). Mediating tourist landscape: A case study of media-induced tourism in China. International Journal of Communication, 7, 2678-2696.

Hudson, S., \& Ritchie, J. B. (2006). Promoting destinations via film tourism: An empirical identification of supporting marketing initiatives. Journal of travel research, 44(4), 387-396. https://doi.org/10.1177/0047287506286720

Ismail, M. N. I., Sumarjan, N., Khan, N. F. A. H., \& Hanafiah, M. H. (2017). Movie touring: The influence of film on viewers' travel intention. In Saufi A., Andilolo I., Othman N., Lew A. (Eds.), Balancing development and sustainability in tourism destinations (pp. 97-108). Singapore: Singapore.

Jebril, N., Albaek, E., \& De Vreese, C. H. (2013). Infotainment, cynicism and democracy: The effects of privatization vs personalization in the news. European journal of communication, 28(2), 105-121.

Jorgensen, Finn Arne (2014). The Armchair traveler's guide to digital environmental humanities. Environmental Humanities, 4, 95-112.

Juskelyte, Donata (2016). Film Induced tourism: Destination image formation and development. Regional Formation and Development Studies, 2(19), 54-67. https://doi.org/10.15181/rfds.v19i2.1283

Karpovich, Angelina I. (2010). Theoretical approaches to film-motivated tourism. Tourism and Hospitality Planning \& Development, 7(1), 7-20. https://doi.org/ 10.1080/14790530903522580

Kellner, D. (2003). Media spectacle. NY: Routledge Taylor \& Francis Group.

Kim, S., \& Reijnders, S. (2017). Asia on my mind: Understanding film tourism in Asia. In Sangkyun Kim, \& Stijn Reijnders (Eds.), Film tourism in Asia evolution, transformation, and trajectory perspectives on Asian tourism (pp.1-18). Singapore: Springer Nature Singapore. https://doi.org/10.1007/978-981-10-5909-4-1

Landry, Charles (2006). The art of city making. London: Earthscan, Routledge.

Lea-Greenwood, G. (2013). Fashion marketing communications. Chichester: John Wiley \& Sons.

Lee, F. L. F. (2002). Radio phone-in talk shows as politically significant infotainment in Hong Kong. Harvard International Journal of Press/Politics, 7(4), 57-79. https://doi.org/10.1177/108118002236350 
Lie, Nadia (2017). The Latin American (counter-) road movie and ambivalent modernity. Leuven: Palgrave Macmillan.

Marinov, R. (2020). Mapping the infotainment literature: Current trajectories and suggestions for future research. The Communication Review, 23(1), 1-28. https://doi.org/abs/10.1080/10714421.2019.1682894

Mazierska, Ewa, \& Walton, John K. (2006). Tourism and the moving image. Tourist Studies, 6(1), 5-11. https://doi.org/10.1177/1468797606070583

Moy, P., Xenos, M. A., \& Hess, V. K. (2005). Communication and citizenship: Mapping the political effects of infotainment. Mass Communication \& Society, 8(2), 111-131.

Nestingen, A. (2005). Aki Kaurismäki's crossroads: National cinema and the road movie. . In Andrew Nestingen, \& Trevor G. Elkington (Eds.), Transnational cinema in a global North: Nordic cinema in transition (pp. 279305). Detroit, Michigan: Wayne State University Press.

Nguyen, A. (2012). The effect of soft news on public attachment to the news: Is "infotainment" good for democracy?. Journalism Studies, 13(5-6), 706-717.

Nizioł, A. (2009). Film tourism as a new way to market a destination. Scientific Review of Physical Culture, 5 (4), $149-156$.

Otto, L., Glogger, I., \& Boukes, M. (2017). The softening of journalistic political communication: A comprehensive framework model of sensationalism, soft news, infotainment, and tabloidization. Communication Theory, 27(2), 136-155. https://doi.org/10.1111/comt.12102

Oviedo-Garcaa, M. A., Castellanos-Verdugo, M., Trujillo-Garcia, M. A., \& Mallya, T. (2016). Film-induced tourist motivations. The case of Seville (Spain), Current Issues in Tourism, 19(7), 713-733. https://doi.org/108o/13683500.2013.872606

Peterson, J. L. (2013). Education in the school of dreams: Travelogues and early nonfiction film. Durham: Duke University Press.

Riley, R. W., \& Van Doren, C. S. (1992). Movies as tourism promotion: A 'pull' factor in a 'push' location. Tourism Management, 13(3), 267-274.

Roesch, Stefan (2009). The experiences of film location tourists. Bristol: Channel View Publications.

Ruoff, J. (2006). Introduction: The filmic fourth dimension: Cinema as audiovisual vehicle. In Jeffrey Ruoff (Eds.), Virtual voyages: Cinema and travel (pp. 1-23). Durham: Duke University Press.

Schultz, B. (2012). Sports media: Reporting, producing, and planning (5th ed.). NY: Focal Press, Elsevier.

Shafik, Viola (1998). Arab cinema history and cultural identity. Cairo: The American University in Cairo Press.

Singh, Kultar (2007). Quantitative social research methods. London: SAGE.

Spears, D. L., Josiam, B. M., Kinley, T., \& Pookulangara, S. (2013). Tourist see tourist do: The influence of Hollywood movies and television on tourism motivation and activity behavior. Hospitality Review, 30(1), 4 . https://digitalcommons.fiu.edu/hospitalityreview/vol3o/iss1/4

Surette, R. (2015). Media, crime, and criminal justice images, realities, and policies (5th ed.). CT: Cengage Learning.

Thussu, Daya Kishan (2003). Live TV and bloodless deaths: War, infotainment and 24/7 news. In Daya Kishan Thussu, \& Des Freedman (Eds), War and the media: Reporting conflict 24/7 (pp. 117-132). London: SAGE Publications.

Thussu, D. K. (2008). News as entertainment: The rise of global infotainment. London: Sage.

Thussu, Daya Kishan (2011). Infotainment Inc.: The ascent of a global ideology. In Stylianos Papathanassopoulos (Eds), Media perspectives for the 21st century (pp. 68-82). NY: Routledge, Taylor \& Francis Group.

Tomala, K., \& Faber, F. (2011). Film tourism. In Alexis Papathanassis (Eds.), The long tail of tourism (pp. 149-158). Wiesbaden: Gabler.

Tussyadiah, I. P., Wang, D., \& Jia, C. H. (2017). Virtual reality and attitudes toward tourism destinations. In Schegg R., \& Stangl B. (Eds.), Information and communication technologies in tourism 2017 (pp. 229-239). Cham: Springer. https://doi.org/10.1007/978-3-319-51168-9

Tzanelli, R. (2007). The cinematic tourist: Explorations in globalization, culture and resistance. NY: Routledge.

Ward, S., \& O' Regan, T. (2009). The film producer as the long-stay business tourist: Rethinking film and tourism from a Gold Coast perspective. Tourism Geographies, 11(2), 214-232. https://doi.org/10.108o/14616680902827175

Zignale, M. (2011). Movie induced tourism in Sicily. Review of Historical Geography and Toponomastics, VI(11-12), 117-121. 